\title{
Determination of Child Vulnerability Level from a Decision-Making System based on a Probabilistic Model
}

\author{
SAHA Kouassi Bernard \\ Laboratory of Computer Science and Telecommunications, \\ National Polytechnic Institute \\ Abidjan, PO Box 475, Côte d'Ivoire \\ BROU Konan Marcelin \\ Laboratory of Mathematics and New Information \\ Technologies, National Polytechnic Institute \\ Yamoussoukro, PO Box 1093, Côte d'Ivoire
}

\begin{abstract}
The purpose of this paper is to provide a decision support tool based on a mathematical model and an algorithm that can help in the assessment of the level of vulnerability of children in Côte d'Ivoire. So, this study was conducted in three phases, the first one includes the settlement of a data warehouse. Then the second involves the application of probabilistic model. The final phase deals with the classification of children considered vulnerable in descending order from the most to the least vulnerable. The purpose of this classification is to better manage the resources of donors to support vulnerable children. This work is part of the activities of UMRI The resilience of Côte d'Ivoire. This is to propose mathematical and computational tools to facilitate the work of the Centre for social resilience. The use of the context of children made vulnerable due to crises or diseases is an example of practical application of our social resilience model
\end{abstract}

Keywords-Crisis; Children; XML data warehouse; data mining; scheduling; Resilience; snowflake pattern; vulnerability level; probabilistic model

\section{INTRODUCTION}

Today, while data abound, resources are dwindling, it is therefore necessary to have a tools for decision support based on computer and information technologies. These are based on data warehouses which are nothing but conventional databases, the only difference being that the underlying model does not use the entity-base relationship formalism. One of the models used to build data warehouses is the snowflake schema. Regarding the activities of social resilience, we necessarily need data storage tools that will be used to support the analysis of data collected in the data warehouse. To offer a dimensional model suitable for the settlement of a data warehouse dedicated to children's resilience. Just as a modeling approach giving an example of the exploitation of data. Thus the use of Bayesian networks technology and dimensional modeling to analyze the level of vulnerability of children in Côte d'Ivoire will be discussed later in this article

\author{
Gooré Bi Tra \\ Laboratory of Mathematics and New Information \\ Technologies, National Polytechnic Institute \\ Yamoussoukro, PO Box 1093, Côte d'Ivoire
}

\author{
Souleymane OUMTANAGA \\ Laboratory of Computer Science and Telecommunications, \\ National Polytechnic Institute \\ Abidjan, PO Box 475, Côte d'Ivoire
}

in order to ease the decision-making of facilitators for the support of children considered vulnerable.

\section{REVIEW OF LITERATURE ON SOCIAL RESILIENCE}

The literature on the concept is very diverse. Etymologically, it means resisting and bounce in front of a significant and persistent adversity. No consensus was reached on the definition of the concept as those proposed are linked to cultural considerations and therefore vary according to societies and also from one period to another. Resilience according to some [1] researchers, is a set of personal characters of the individual (or group of individuals), a process and an outcome. It is part of a learning process, selfdetermination through which the person interprets the meaning of a situation of adversity positively and reorient the direction of his life to pursue its development while strengthening its protective personal or environmental factors. However, with the situation of adversity as new self-organizer of the individual. However, all of them have in common the ability to bounce back from a shock and adapt to change [2] [3]. In this perspective, any measures of resilience require the observation of the demonstration of several dimensions. The definition used in this study is that of Tisseron [4] "Resilience is both the ability to withstand the trauma and to recover after it.

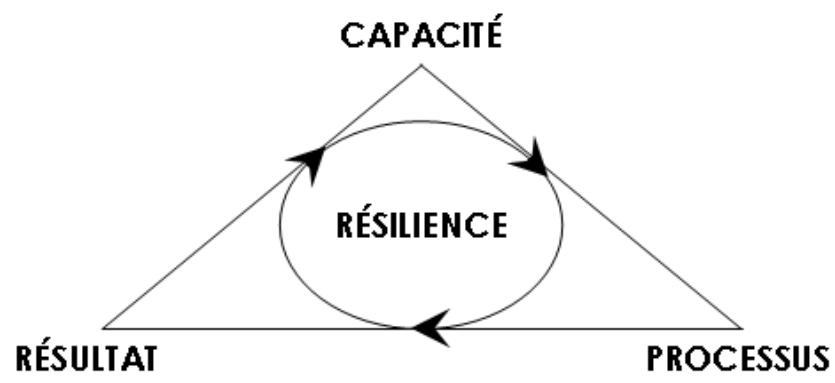

Fig. 1. Model illustrating the resilience [9] 


\section{Dimensional Modeling OF VULNERABLE CHILDREN JUDGED RESILIENCE DATA}

In Côte d'Ivoire, the issue of vulnerable children support has led Organizations to put into place monitoring systems and feedback devices without forgetting their care taking. Very often support policies emanate from international programs. In That way, dimensional modeling aims to present data in a standardized form to facilitate intuitive querying of data. The subject for analysis is in the center of the model (fact table) and the relevant area to be analyze are attached to it (dimensions).The following table presents the different dimensions included in the monitoring and evaluation system of vulnerable children by NGOs led by HOPE-CI and funded by an American government led program called PEFAR section Cote d'Ivoire.

TABLE I. MONITORING AND EVALUATION DiMENSIONS OF VULNERABLE CHILDREN FROM CSI1

\begin{tabular}{|c|c|c|}
\hline DIMENSIONS & ATTRIBUTES & ARRANGEMENTS \\
\hline \multirow{2}{*}{$\begin{array}{l}\text { Food and } \\
\text { nutrition }\end{array}$} & Food Safety & $\begin{array}{l}\text { Although, Average, Poor; } \\
\text { Very bad }\end{array}$ \\
\hline & $\begin{array}{l}\text { Growth and } \\
\text { Nutrition }\end{array}$ & $\begin{array}{l}\text { Although, Average, Poor; } \\
\text { Very bad }\end{array}$ \\
\hline \multirow{2}{*}{$\begin{array}{l}\text { Education and } \\
\text { Performance }\end{array}$} & Education & $\begin{array}{l}\text { Although, Average, Poor; } \\
\text { Very bad }\end{array}$ \\
\hline & Performance & $\begin{array}{l}\text { Although, Average, Poor; } \\
\text { Very bad }\end{array}$ \\
\hline \multirow{2}{*}{$\begin{array}{l}\text { Housing and } \\
\text { care }\end{array}$} & housing & $\begin{array}{l}\text { Although, Average, Poor; } \\
\text { Very bad }\end{array}$ \\
\hline & care & $\begin{array}{l}\text { Although, Average, Poor; } \\
\text { Very bad }\end{array}$ \\
\hline \multirow{2}{*}{ Health } & Health & $\begin{array}{l}\text { Although, Average, Poor; } \\
\text { Very bad }\end{array}$ \\
\hline & Health services & $\begin{array}{l}\text { Although, Average, Poor; } \\
\text { Very bad }\end{array}$ \\
\hline \multirow{2}{*}{ psychosocial } & Emotion & $\begin{array}{l}\text { Although, Average, Poor; } \\
\text { Very bad }\end{array}$ \\
\hline & Social behavior & $\begin{array}{l}\text { Although, Average, Poor; } \\
\text { Very bad }\end{array}$ \\
\hline \multirow{2}{*}{ Protection } & $\begin{array}{l}\text { Abuse and } \\
\text { Exploitation }\end{array}$ & $\begin{array}{l}\text { Although, Average, Poor; } \\
\text { Very bad }\end{array}$ \\
\hline & Juridic protection & $\begin{array}{l}\text { Although, Average, Poor; } \\
\text { Very bad }\end{array}$ \\
\hline
\end{tabular}

The table shows the structure of monitoring and evaluation information allowing to assess the level of vulnerability and resilience of vulnerable children. Starting from this, we can construct an improved dimensional model, adapted to the implementation of data warehouse and the monitoring and assessment of the level of children's vulnerability. In fact, dimensional modeling, and notably the snowflake schema, is well known for its effectiveness in developing solutions in decision making. It is easily exploitable for developing reporting applications and dashboards. From a conceptual standpoint dimensional modeling is related to the concepts of fact and dimension:

\section{Subject $=($ fact + dimension $)$}

The snowflake schema derived from Table 1 is given by the following figure:

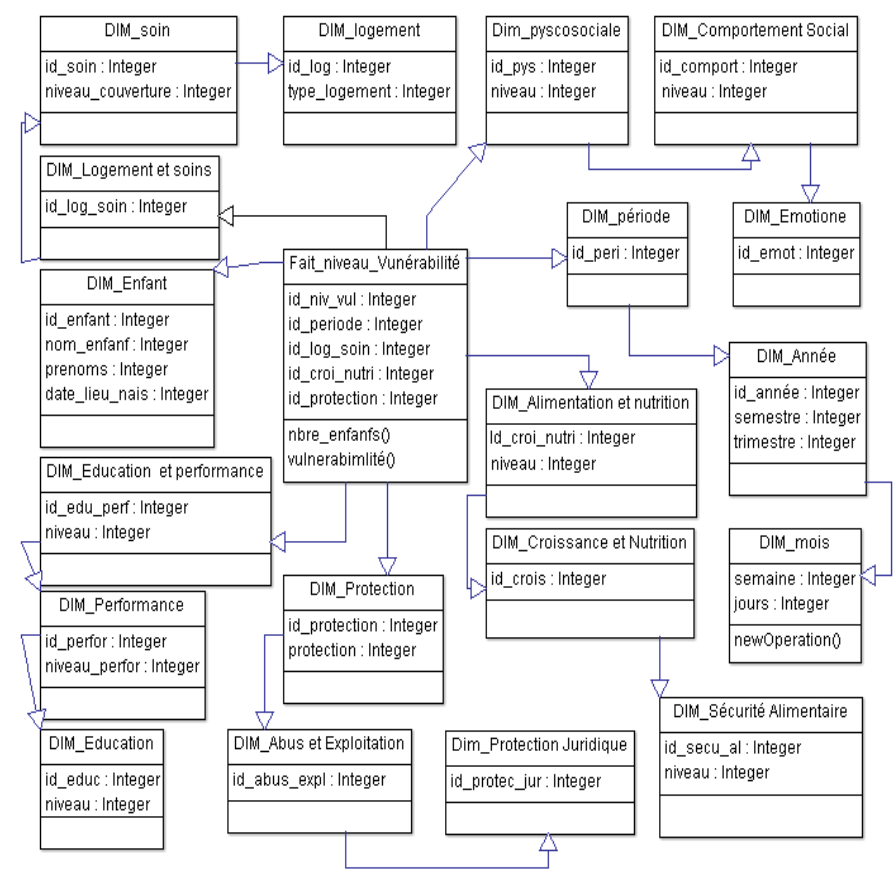

Fig. 2. The dimensional model snowflake vulnerable children

To succeed in the implementation of the snowflake schema, the schema of the basis must be the same as the one currently used (spreadsheet) be converted into the format of the data warehouse by ETL program. In addition to this, the quality of stored data should be considered in the practical implementation of the data warehouse. For good data quality, it is still possible to extract useful data for a multidimensional search, achieving, by the way, all the necessary corrections for their operation. The interest of having a data warehouse is to be able to regularly examine the resilience of vulnerable children in order to optimize the financial resources deployed by donors. [5] Several non-governmental organizations and public health facilities are overwhelmed with data but do not have the information they need to make good decisions. Knowing that they have all the data in warehouses can help these organizations optimize their decision making. Therefore, the research on vulnerable children, the analytical method requires methods that are easy to update and that provide a simple and efficient simulation approach. In this context, Bayesian Networks technology is the right approach because of its character both qualitative (these algorithms) and quantitative (embedded graphs). [6] The following figure shows the functional architecture of the core application of the decision-making system to create.

\footnotetext{
${ }^{1}$ CSI: Children Status Index record (Index of Child Status Rating)
} 


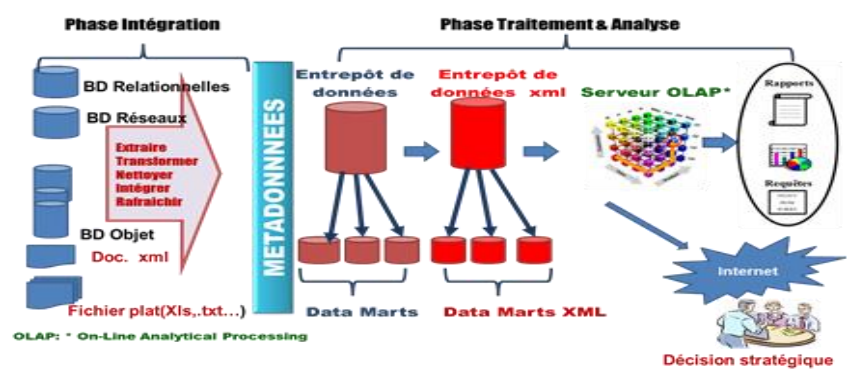

Fig. 3. Functional architecture of XML DW

\section{BAYESIAN NETWORK RESILIENCE MODELING}

Also known as probabilistic expert systems, Bayesian Networks are tools of knowledge representation and automated reasoning on that knowledge. They were introduced by Judea Pearl in the 1980s and are found to be powerful useful tools for representing uncertain knowledge and reasoning from incomplete information. Bayesian Networks are simulation tools for observing the behavior of a complex system in contexts and conditions that are not necessarily accessible to experimentation. Technically, Bayesian networks are graphical models combining graph theory and probability theory. The following diagram (2) shows an example of Bayesian Network [8]:

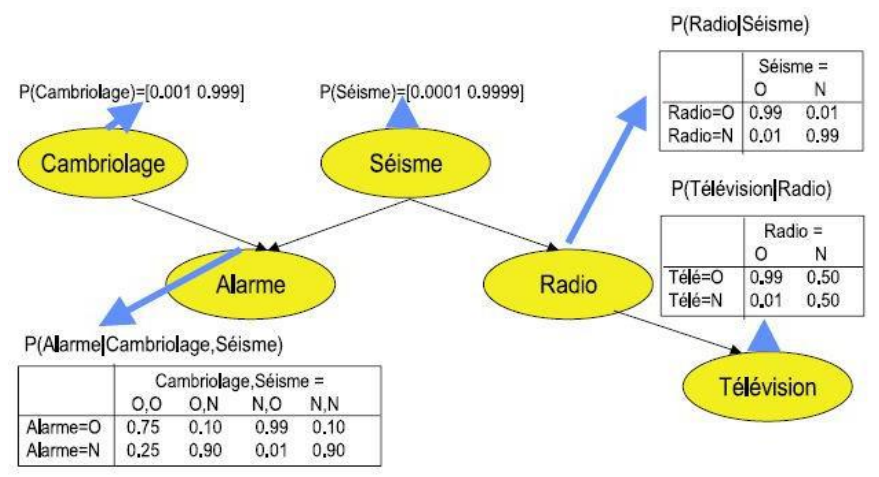

Fig. 4. Example of Bayesian Network

The above diagram is taken from a tutorial presented at the $8^{\text {th }}$ scientific meeting dedicated to Knowledge Discovery in Data from (Philippe Leray). This Bayesian Network [09] models the process of triggering a security alarm in an environment frequently subjected to earthquakes. These earthquakes affect radio facilities upon which the television infrastructure is built. As shown in figure (Fig 2), a Bayesian network is a directed graph in which nodes represent the variables and the arcs symbolize the dependency relationships between these variables. Each node has a conditional probabilities table that is a model of beliefs in the occurrence of a particular case when we are in such a condition.

\section{Probabilistic Modeling of THE RESILIENCE OF VULNERABLE CHILDREN}

According to the review of literature, the Bayesian Networks were introduced by Judea Pearl in the 1980s and turned out to be powerful and useful tools for representing uncertain knowledge and reasoning from incomplete information. Representational knowledge to and automated reasoning about knowledge. Bayesian Networks are simulation tools to observe the behavior of a complex system in contexts and conditions that are not necessarily accessible to experimentation. Technically, Bayesian networks are graphical models combining graph and probability theory. In the framework of the modeling of the process of identification of best actions of resilience process, the graph of Bayesian networks reflects the identified actions and decision variables thereon. The graph of figure 4 depends on the computer model that helped create the data warehouse. [10] We will use the graphic function of the software GeNIes ${ }^{2}$, Which is a powerful simulation Bayesian network tool and especially free, to model the process of understanding the level of child vulnerabilities. The following chart provides the structure of relationships between the different attributes:

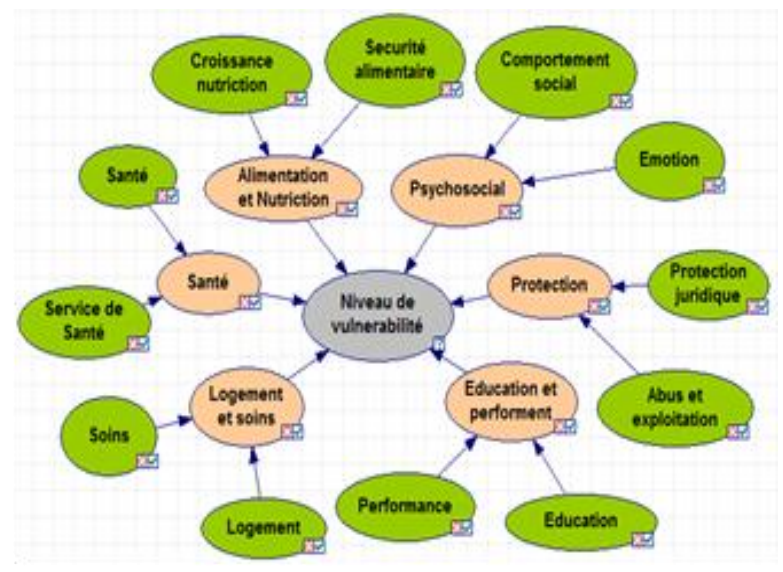

Fig. 5. Structure of Bayesian Network developed from the flake dimensional model

The above graph presenting the structure is an intuitive representation of the dimensions of resilience that governs the process of detection of children's vulnerability level. This representation was obtained after the introduction of the dimensions obtained from the dimensional model proposed flake. This graph of dependencies of Figure 4, is the qualitative part of the corresponding Bayesian network model. Although the conditional probabilities can be provided by experts in the field, the fact of having already structured data provides more accurate estimates of these probabilities.

\section{ASSOCIATION GATE DESIGN FOR BEARING-ONLY TARGET TRACKING}

In practice there are many free software developed for their implementations. This reflects their importance in the field of machine learning [11]. For this project we have decided to implement the data warehouse part of our contribution on a free software Pentaho which integrate both tools, ETL, OLAP and reporting tools with a possibility to use data mining techniques for the analysis. Once the parameters are estimated by the application, the use of Bayesian Networks is to simulate the effects, of a number of choices on all other actions and variables included in the model developed. It includes a large number of learning algorithms as well as the

\footnotetext{
${ }^{2}$ Website : https://dslpitt.org/genie/
} 
parameters of the structure from the data [12]. It also has a friendly interface and can easily be used by non-specialists in modeling, including policymakers. For the simulation phase we will classify through an algorithms the degree of vulnerability of children considered vulnerable in the first algorithm with Bayesian networks. For the practical phase we are going from the base end of the first simulation data with GeNies3 Use the R language to run our algorithm on a sample of 51 children (Table 3). After that we will analyze the new results and finally we would draw a conclusion. Here is the scale of values transcribed in the table below.

TABLE II. INCREASING SCALE OF THE LEVEL OF VULNERABILITY

\begin{tabular}{|l|l|l|l|l|}
\hline \multicolumn{1}{|c|}{ status } & $\begin{array}{l}\text { very } \\
\text { vulnera } \\
\text { ble }\end{array}$ & $\begin{array}{l}\text { vulne } \\
\text { rable }\end{array}$ & $\begin{array}{l}\text { Acceptabl } \\
\text { e }\end{array}$ & resilient \\
\hline $\begin{array}{l}\text { Intervals of } \\
\text { the scores }\end{array}$ & $\begin{array}{l}\text { Rubbish } \\
\text { (n) }\end{array}$ & $\begin{array}{l}\mathrm{Bad}> \\
50 \%\end{array}$ & $\begin{array}{l}\text { Average> } \\
50 \%\end{array}$ & $\begin{array}{l}\text { Good> } \\
50 \%\end{array}$ \\
\hline $\begin{array}{l}\text { increasing } \\
\text { scale }\end{array}$ & 1 & 2 & 3 & 4 \\
\hline
\end{tabular}

TABLE III. EXTRACTED FROM THE DATABASE R

\begin{tabular}{|c|c|c|c|}
\hline & N..Ordre & NomE & NV \\
\hline 1 & 1 & COULIBALY AWA & 1 \\
\hline 2 & 2 & KONE TIEKOURA & 3 \\
\hline 3 & 3 & ROUAROU MAURICE & 3 \\
\hline 4 & 4 & $N^{\prime}$ GUESAN GERARD & 2 \\
\hline 5 & 5 & KOFEI YAO SERGE & 1 \\
\hline 6 & 6 & ROBENAN ALI & 1 \\
\hline 7 & 7 & OUTTARA NOUHO & 2 \\
\hline 8 & 8 & KANGAH KOFFI & 3 \\
\hline 9 & 9 & ADEPAUD HERVE & 1 \\
\hline 10 & 10 & COULIBALY AYA & 3 \\
\hline 11 & 11 & KONE TIEROURA & 3 \\
\hline 12 & 12 & KOUAROU EDIE & 2 \\
\hline 13 & 13 & N'GUESAN MEDARD & 2 \\
\hline 14 & 14 & YAO KONAN ALBERT & 2 \\
\hline 15 & 15 & ROBENAN ALI & 1 \\
\hline 16 & 16 & OUTTARA JEROME & 3 \\
\hline 17 & 17 & RANGAH ROFFI & 4 \\
\hline 18 & 18 & KARNAN JEROME & 1 \\
\hline 19 & 19 & COULIBALY AWA & 2 \\
\hline 20 & 20 & RONE TIEROURA & 2 \\
\hline 21 & 21 & KOUAKOU MAURICE & 2 \\
\hline 22 & 22 & ROUASSI ADLES & 2 \\
\hline 23 & 23 & YAO SERGE & 2 \\
\hline 24 & 24 & KOBENAN ALI & 1 \\
\hline 25 & 25 & OUTTARA DRISSA & 2 \\
\hline
\end{tabular}

\begin{tabular}{|l|l|l|l|}
\hline 26 & 26 & KANGAH KOFFI & 3 \\
\hline 27 & 27 & KOUYATE BENGALI & 1 \\
\hline 28 & 28 & COULIBALY ABIBA & 2 \\
\hline 29 & 29 & KONE TIEMOMAN & 1 \\
\hline 30 & 30 & KOUAROU MAURICE & 3 \\
\hline 31 & 31 & N'GUESAN GERARD & 2 \\
\hline 32 & 32 & YAO YAO SERGE & 3 \\
\hline 33 & 33 & KOBENAN ALI & 2 \\
\hline 34 & 34 & OUTTARA NOUHO & 1 \\
\hline 35 & 35 & KANGAH ROFFI & 2 \\
\hline 36 & 36 & KONE MALICR & 3 \\
\hline 37 & 37 & COULIBALY ANA & 2 \\
\hline 38 & 38 & KONE TIEKOURA & 3 \\
\hline 39 & 39 & KOUASSI MADISON & 3 \\
\hline 40 & 40 & N'GUESAN GERARD & 1 \\
\hline 41 & 41 & YAO SERGE & 2 \\
\hline 42 & 42 & KOBENAN ALI & 2 \\
\hline 43 & 43 & BGAME SILVAIN & 2 \\
\hline 44 & 44 & KANGAH ROFFI & 2 \\
\hline 45 & 45 & KONATE NAVIGUE & 2 \\
\hline 46 & 46 & COULIBALY MANA & 1 \\
\hline 47 & 47 & KONATE TIEROURA & 2 \\
\hline 48 & 48 & KOUAKOU MICHEL & 2 \\
\hline 49 & 49 & KONAN GERARD & 3 \\
\hline 50 & 50 & YAO KOUAROU & 3 \\
\hline 51 & 51 & TOURE ALI & 3 \\
\hline & & & \\
\hline
\end{tabular}

\begin{tabular}{|ll|}
\hline \multicolumn{2}{|c|}{ ALGO matrix_ordonnancement } \\
1 & Entrance \\
2 & popu: child list \\
3 & beginning \\
3 & browse popu; \\
4 & each iteration comparing the value \\
5 & vulnerability to the previous item \\
6 & that of the next item; \\
7 & Yes Previous item value> then next \\
& item value \\
$\mathbf{8}$ & Repeat browse popu until there \\
10 & is more permutation \\
11 & display ranked list () \\
12 & END \\
\hline
\end{tabular}

Fig. 6. Pseudo scheduling algorithm level of vulnerability

\begin{tabular}{|c|c|c|}
\hline$=$ & acepavo moravr & $=$ \\
\hline$z$ & paauer sxzvarse & a \\
\hline 3 & coctrater zoral & $=$ \\
\hline 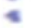 & couzzaAzy axa. & $a$ \\
\hline $\mathbf{s}$ & coozzanzy Ara & $=$ \\
\hline$\leftarrow$ & 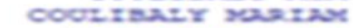 & $\mathrm{z}$ \\
\hline 7 & ocostracy raxa & a \\
\hline$=$ & 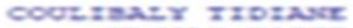 & $=$ \\
\hline $\mathbf{3}$ & ravedaur mogrz & a \\
\hline$=0$ & ravedaue nockas & $=$ \\
\hline 22 & raveane roctapto & $\mathrm{a}$ \\
\hline 22 & 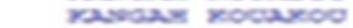 & a \\
\hline 23 & 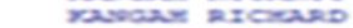 & $z$ \\
\hline 24 & ravolase reacher & $z$ \\
\hline 25 & noorsave antan & $z$ \\
\hline 26 & noberase acz & $z$ \\
\hline 20 & norgz rao sxinger & $z$ \\
\hline 22 & poscas aralab & $z$ \\
\hline 22 & noecate savzour & 2 \\
\hline 23 & 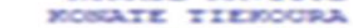 & $z$ \\
\hline 24 & nose matrex & 2 \\
\hline 25 & mocect izexocusa & $z$ \\
\hline 29 & 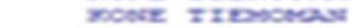 & 2 \\
\hline 30 & yocravool rotr: & 2 \\
\hline 32 & noclarod rasples & $z$ \\
\hline 34 & 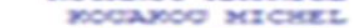 & 2 \\
\hline 35 & mociassi abers & $z$ \\
\hline 36 & rocassz rabrscose & 3 \\
\hline
\end{tabular}

Fig. 7. List of children by level of vulnerability $\mathrm{R}$

The TABLE III shows an excerpt of data sorted by the proposed algorithm Figure5. This algorithm also provides a graphical visualization of single child vulnerability of the state being in the database grouped by degree of vulnerability as shown in figure 6:

\footnotetext{
${ }^{3}$ Website : https://dslpitt.org/genie/
} 
TABLE IV. EXTRACTED FROM THE DATABASE BASED ON SLICES

\begin{tabular}{|c|c|c|c|c|c|}
\hline \multirow{2}{*}{ Children age group } & \multirow{2}{*}{$\begin{array}{l}\text { Number } \\
\text { of children } \\
\text { assessed }\end{array}$} & \multicolumn{4}{|c|}{ Food Safety } \\
\hline & & 1 & 2 & 3 & 4 \\
\hline $\begin{array}{l}\text { Aged } 0 \text { to } 23 \\
\text { months }\end{array}$ & 1 & 0 & 0 & 1 & 0 \\
\hline Boys 2 to 4 years & 8 & 0 & 2 & 6 & 0 \\
\hline $\begin{array}{l}\text { Boys aged } 5 \text { to } 9 \\
\text { years }\end{array}$ & 8 & 0 & 0 & 8 & 0 \\
\hline Boys 10 to 14 years & 5 & 0 & 1 & 4 & 0 \\
\hline $\begin{array}{l}\text { Boys } 15 \text { to } 17 \text { years } \\
\text { old }\end{array}$ & 2 & 0 & 1 & 1 & 0 \\
\hline total Boys & 24 & 0 & 4 & 20 & 0 \\
\hline Boy total control & & & 24 & & \\
\hline $\begin{array}{l}\text { Girls aged } 0 \text { to } 23 \\
\text { months }\end{array}$ & 0 & 0 & 0 & 0 & 0 \\
\hline $\begin{array}{l}\text { Daughters of } 2 \text { to } 4 \\
\text { years }\end{array}$ & 5 & 0 & 2 & 3 & 0 \\
\hline Girls 5 to 9 years & 8 & 0 & 3 & 5 & 0 \\
\hline Girls aged 10 to 14 & 8 & 0 & 2 & 6 & 0 \\
\hline $\begin{array}{l}\text { Girls } 15 \text { to } 17 \text { years } \\
\text { of age }\end{array}$ & 6 & 0 & 0 & 6 & 0 \\
\hline total Girls & 27 & 0 & 7 & 20 & 0 \\
\hline Girls total control & & & 27 & & \\
\hline $\begin{array}{l}\text { TOTAL Boys \& } \\
\text { Girls }\end{array}$ & 51 & 0 & 11 & 40 & 0 \\
\hline $\begin{array}{l}\text { Total } 0 \text { to } 23 \\
\text { months }\end{array}$ & 1 & 0 & 0 & 1 & 0 \\
\hline $\begin{array}{l}\text { Total of } 2 \text { to } 4 \\
\text { years }\end{array}$ & 13 & 0 & 4 & 9 & 0 \\
\hline $\begin{array}{l}\text { Total of } 5 \text { to } 9 \\
\text { years }\end{array}$ & 16 & 0 & 3 & 13 & 0 \\
\hline $\begin{array}{l}\text { Total of } 10 \text { to } 14 \\
\text { years }\end{array}$ & 13 & 0 & 3 & 10 & 0 \\
\hline $\begin{array}{l}\text { Total } 15 \text { to } 17 \\
\text { years old }\end{array}$ & 8 & 0 & 1 & 7 & 0 \\
\hline
\end{tabular}

Legendre:

1: Highly Vulnerable, 2: Vulnerable, 3: Good 4: Resilient Histogram of vulnerability level

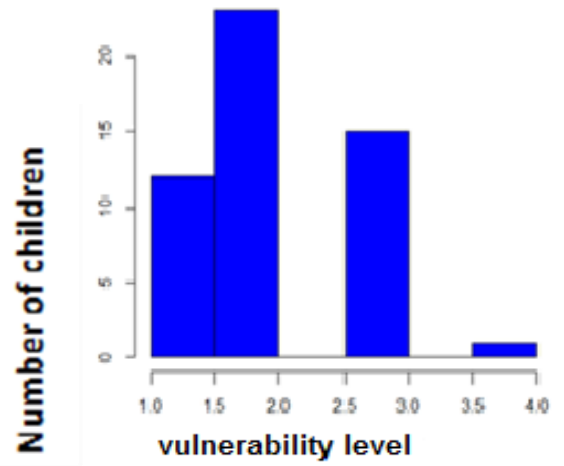

Fig. 8. Overall level of vulnerability of children-wide growth

For an interpretation we will consolidate the results on the level of vulnerability of children per age group. They will be classified according to the dimensions of social resilience.
Here are the different age ranges ([0 to 23 months], [2-4 years], [5-9 years], [10 to 14], [15 to 17])).

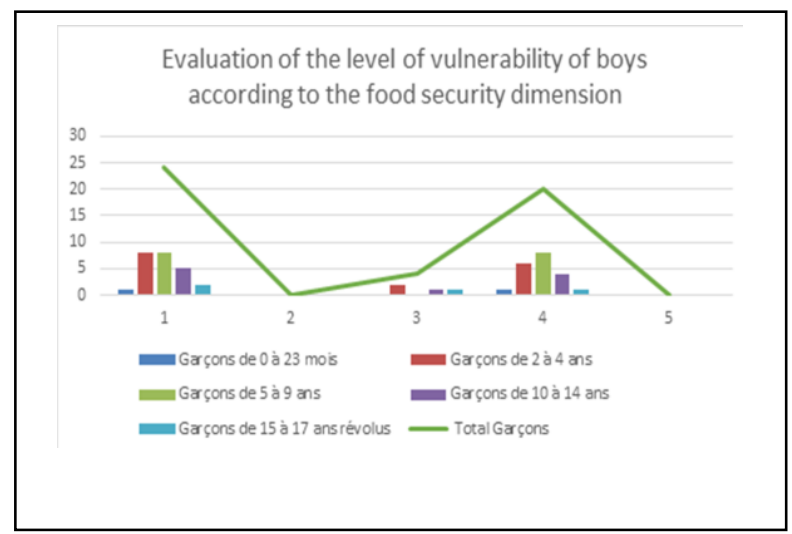

Fig. 9. Simulation result of the level of vulnerability of boys to food security dimension

These figures illustrate an example of evaluation according to food security dimension; it will be the same for the evaluation of each of the different dimensions in the end a conclusion will be drawn.

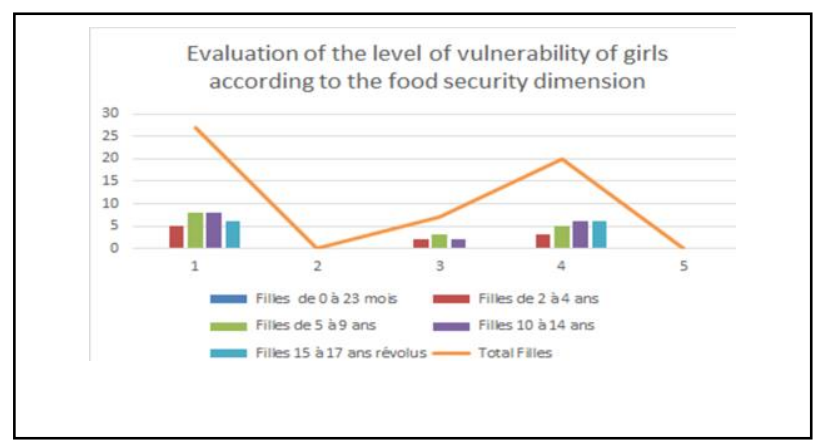

Fig. 10. Overall Level of girls' vulnerability to food security dimension by age group

The pace and curves of the graphs show the level of vulnerability among both young boys and girls is almost identical. Besides, considering the age range of the children, between [5-10] are less vulnerable than others see Figures 8 and 9.

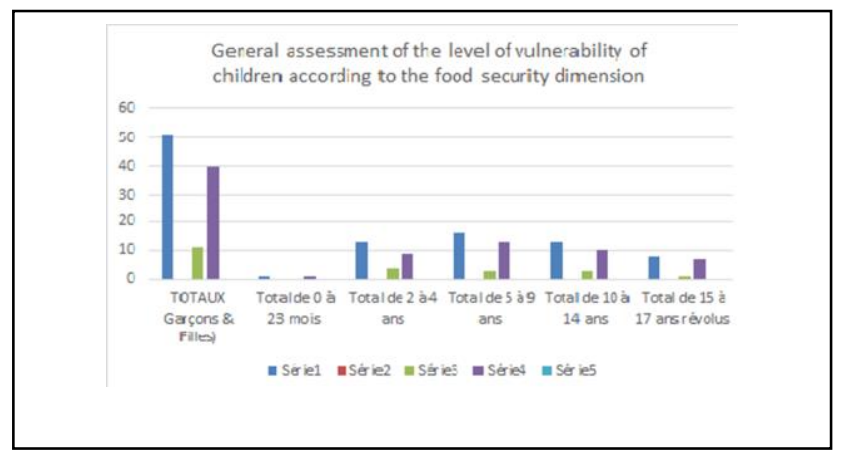

Fig. 11. Overall level of vulnerability of children (girls and boys) for food security dimension

In a word, it appears from this experience that whatever the sex of the children, the most vulnerable age group is the 
range between [2-10] years for food security dimension. This could be explained by the fact that children at this age begin a growth phase, it then takes more resources to the parents to diversify their diet. However we usually have to do with orphans who live with guardians sometimes in households considered vulnerable themselves [12].

\section{CONCLUSION}

The care for children in difficulty in order to reduce the level of poverty in African states and even in developing countries is a major issue. Non-governmental organizations and international organizations such as PUNUD, WHO and UNAIDS regularly develop and fund projects for their support. But, the resources are limited in face of the needs expressed. So, there is a need to use mathematical and computational tools in order to optimized management of these resources, for the storage of information collected in a data warehouse will significantly improve not only the management of these data, but also their use for purposes of decision support, particularly in the understanding of the process of the resilience of vulnerable children .In the framework of the analysis of resilience in general and that of vulnerable children in particular, the Bayesian networks are particularly appropriate owing to the fact that they are adapted to situations where one is confronted with incomplete, inaccurate and uncertain data. The use of simulation GeNies ${ }^{4}$ helps us just to know the status of a child. To know the children whose situation requires an imminent and total support? Also, on top of the knowledge of their status, they must be determined and classified according to their level of vulnerability. This will enable organizations to make optimal management of resources allocated by donors. The major advantage that our contribution will make is that it assesses the dimensions and function separately based on the sex Children. This helps understand the importance and the impact of a dimension on the whole. As regards the results indicated on the figure above in all there are not any vulnerable or resilient children.

\section{REFERENCES}

[1] Bahadur, AV, Ibrahim, M. \& Tanner, T. 2010. The resilience renaissance? Unpacking of Resilience for Tackling climate change and disasters. Strengthening Climate Resilience Discussion Paper 1. Brighton, UK, Institute of Development Studies, University of Sussex. Available at: http://community.eldis.org/.59e0d267/resiliencerenaissance.pdf. Accessed August 10, 2012.

[2] Anaut M. (2003) Resilience: Overcoming trauma, Ed. Nathan University.J. Clerk Maxwell, A Treatise on Electricity and Magnetism, 3rd ed., vol. 2. Oxford: Clarendon, 1892, pp.68-73.

[3] Anaut, M. (2002). Trauma, and Vulnerability Resilience in Child Welfare. Connections magazine, Eres, Volume 77, 101-118.

[4] TISSERON, S. Virtual adolescence: self-destruction or self-help? Neuropsychiatry of childhood and adolescence, 2007, Vol. 55, No. 5, p. 264-268.

[5] Achiépo Odilon Mr. Yapo (2015). "Plspm. formula: Formula Based PLS Path Modeling". R Package version 1.0.1, December 2015. https://cran.r-project.org/package=plspm.formula.

[6] Narchi Saud, Joelle. Factors associated with resilience of family caregivers of an elderly parent with loss of independence at home in Lebanon. 2014.

[7] TIEKOURA, Coulibaly Kpinna and BOKO Aka. SimCT: A measure of semantic similarity to adapté hierarchies of concepts. International Journal of Computer Science and Information Security, 2016, vol. 14, No

[8] SAHA Bernard Kouassi, ACHIEPO Odilon Mr. Yapo, BROU Konan Marcelin, et al. Storage and Bayesian modeling of data on the social resilience: Case of Orphans and Vulnerable Children (OVCs) in Ivory Coast. International Journal of Computer Science Issues (IJCSI), 2015, vol. 12, No. 4, p. 137.

[9] R. Kimball, R. Mertz, "The Data Webhouse: Building the Web-enabled Data Warehouse", John Wiley \& Sons, 2000;

[10] Von Overbeck Ottino S. (2002) Mental Health in the city. Resilience in psychotherapeutic work: what psychological support for children exposed to mob violence? in psychiatric Papers, No. 29, BDSP.

[11] SAHA Bernard Kouassi, BROU Konan marcelin, Babri Michel, et al. Classification of Households in after-traumatic shock, with the aid of Bayesian Networks: example of the post-electoral crisis in Côte d'Ivoire. International Journal of Computer Science and Information Security (IJCSIS), 2016, vol. 14, No. 7, p. 201.

[12] Melaine Achiépo Odilon Yapo, ABIDJAN, Ivory Coast, PATRICE, Mensah Edoeté, et al. Resilometrics: Principles of the Discipline and the Resilience Measure Models. International Journal of Computer Science and Information Security, 2016, vol. 14, No. 5, p. 162

\footnotetext{
${ }^{4}$ Website : https://dslpitt.org/genie/
} 